Brit. J. industr. Med., 1948, 5, 185

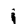

\title{
VICTUALS AND VENTILATION AND THE HEALTH AND EFFICIENCY OF SEAMEN
}

\author{
BY \\ F. P. ELLIS \\ From the Royal Naval Personnel Research Committee (Medical Research Council)
}

(RECEIVED FOR PUBLICATION, MAY 26, 1948)

The importance of good victuals and sound methods for ventilating ships to the maintenance of health and efficiency of seamen is so well known that it may appear unnecessary to ask if the lessons and examples with which British naval history. abounds are given the full consideration they merit in modern warship design and operation.

We are, however, at the dawn of a new age in naval development as in many other spheres of interest. In the same way as the coastal voyages of the slave-driven galleys of ancient times and the Middle Ages gave way, following the introduction of the mariners' compass by Prince Henry of Portugal, to the great navigations of the fifteenth, sixteenth, and seventeenth centuries and the maritime wars of the eighteenth; so now may the steam and motor-driven vessels of the nineteenth and twentieth centuries to which we are accustomed be replaced by ships of new design, not only propelled at high speeds by new forms of power, but also - greatly modified in structure because of the possibilities of future aerial, submarine, biological, and atomic warfare, and equipped to a high degree with complicated devices and weapons requiring skill, discrimination, and sustained concentration for their successful operation.

Future developments cannot fail to affect the naval way of life ; and enough has been seen in recent years of what can happen when the gadgeteer is allowed to run wild, to warn those responsible for the welfare and health of the men to keep a weather eye on plans for the future, and to ensure that the lessons of the past as well as those of the present are not neglected.

\section{Historical Background}

Until the reign of Henry VIII warships as such did not exist. Seaborne traffic was carried on by merchantmen, heavily armed, which were chartered by the King when he required them to carry his armies across the Channel for the wars with France. The sixteenth century, however, was one of great discovery. After Vasco da Gama's voyage to the East Indies in 1493, and after Cabot had sailed to Newfoundland from Bristol in 1496, the Merchant Adventurers' Company was set up in 1505. Magellan rounded Cape Horn in 1520 ; in 1530 William Hawkins sailed to Guinea and Brazil ; Richard Chancellor navigated the Northern Sea to visit Moscow in 1553 and founded the Muscovy Company ; in 1577-80 Drake circumnavigated the globe, and on December 31, 1600, the East India Company was formed.

Moore (1911) stresses the poor understanding of ship ventilation and the neglect of human requirements which undermined the health of the Fleet under Henry VIII, and he describes how, when Calais was lost in the time of Mary, the spread of disease contributed largely to the ineffectiveness of the British forces. Even the great naval battle of 1588 which resulted in the defeat of the Armada was fought by a British Fleet which was largely ravaged by epidemics. Letters from the Lord High Admiral, Howard of Effingham, to Burleigh and Walsingham continually stressed the need for replasing sick men and for providing money for clothes and other necessities for the crews who were in a parlous state after eight months at sea ; and they told also of the attempts made to defeat the scourge by cleaning out ballast, airing ships with fires, and renewing ships' companies. The winds scattered the enemy but the English losses from disease were desperately heavy:a

Disease flourished particularly amongst the conscript motley of landsmen who were impressed in those days to serve in warships in times of national crisis. The tried and picked crews who signed on for special expeditions between the wars to sail under commanders such as Drake, who had care for the needs of their men, fared much better. 
Indeed, had it not been so, voyages such as the circumnavigation of the globe by the Pelican (renamed the Golden Hind during the voyage) over a period of three years would have resulted in disaster. Even Drake had his troubles, however, and it is reported that he lost 600 out of 2,300 men from illness in ships which undertook an expedition under his command in 1585-86.

The decline of British seapower under the early Stuarts brought no amelioration to the lot of seamen. James I, described as " the most thoroughgoing Pacifist who ever bore rule in England," did little for them, and under Charles I warships were often little-more than floating pest-houses. The high mortality amongst crews was repeatedly attributed by those in authority in the Fleet to poor and inadequate victuals, shortage of clothing, and appalling personal hygiene. Expedition after expedition failed because of the heavy toll of disease in ships' companies comprised largely of impressed landsmen who did not know how to live in ships and were unwilling to learn. This desperate state of affairs persisted, but not from lack of reports from commanders, whose suggestions for improvements were rarely implemented. For example, Captain John Smith (1626) in his " Accidence for Young Seamen" recommended in his "Petty Tally" an ample and varied diet including the "Juyce of Lemons for the Scurvey." It was, however, 150 years before this frequently advocated and provedly effective remedy became a general issue.

Under the Commonwealth, and with the influence of Blake, more human consideration was shown to sailors. An Admiralty Committee made recommendations concerning special provisions, landing of the sick, and the provision of old linen for dressing wounds. This considerate attitude appears to have continued in the Restoration period, and in 1665 the Navy apparently remained free from plague, owing to a wise policy of isolating the crews on board when many were dying ashore.

The Royal Navy was not created in name until the reign of Charles II, following the great victories of Blake, who insisted that the State ships should be designed and maintained primarily for battle purposes. For the next sixty or seventy years, however, the Fleet operated for the most part against the French, Dutch, and Spanish in the narrow waters of the English Channel, and naval warfare did not become a world-wide affair until the latter half of the eighteenth and the early nineteenth centuries, when lengthy blockades of the European ports kept the Fleet at sea for many months on end.

The severe conditions of the Napoleonic Wars brought home to the authorities the necessity for improving the lot of seamen and resulted in many reforms, which, blended with the introduction of steam propulsion and iron hulls during the comparatively peaceful Victorian era, led to the evolution of the standards of living and working conditions in warships as we find them today.

\section{Scurvy}

Scurvy appears to have been primarily a disease of comparatively modern times. Lind (1772), in a most comprehensive thesis, observes that although Hippocrates described an illness which was almost certainly scurvy, the succeeding Greek and Roman authors apparently did not know it. He attributed this to their scanty knowledge of northern waters and also to " their short coasting voyages," and these limitations applied to the experience of the majority of those that followed them for many years, although records are scarce.

With improved methods of navigation and the discovery of the Indies in the fifteenth century, the first recent account of this disease appeared in the chronicles of Vasco da Gama (1497), who lost a hundred men from his crew of 160 during his voyage around the Cape of Good Hope to the East Indies. Jacques Cartier, after his second voyage to the Saint Lawrence River in 1536, gave a vivid description of a disease which broke out amongst the garrison ashore which was probably scurvy and which responded rapidly to concoctions made from the leaves of a shrub (the hanneda) which was advocated as a remedy by the Indians.

The disease was not generally recognized, however, probably until long voyages away from land became more common, for the "incubation period" for scurvy appeared to be three to four months; thus the sea voyage of Columbus (1496) was completed well within this time, and they did not suffer from this disease.

Underwood (1947) points out that the relation of the lemon to the cure of conditions which were probably scorbutic was known from very early times, and refers to a monograph-De Limonibus Tractatus-extracted from the Arabic work of Ibn-al-Baitar (1197-1248) and translated into Latin by Andreas Alpagus which was published in Paris in 1602. It would appear that oranges and citrons were first introduced into England towards the end of the thirteenth century, but no references were made to their curative properties in treating scurvy before the end of the sixteenth century.

Underwood considered that Richard Hawkins of the Daintie in 1593 was the first commanding officer to plan to cure scurvy with oranges and lemons, which he procured on arrival at Santos in Brazil when bound for the Magellan Straits; James 
Lancaster, in 1601, was the first to use lemon juice as a prophylactic; and Woodall (1617) was the first British ship's surgeon to extol the virtues of the lemon both in cure and prevention.

Lind abstracted the works of seventy writers of the sixteenth, seventeenth, and eighteenth centuries, who described the disease at first as an affection of armies and landsmen, although it was observed at an early time amongst the Dutch seamen. Then during the next two hundred years a succession of observers, in addition to those named above and including Don Sebastian Viscaino (1602), Drawitzs (1647), Cockburn (1696), Bachstrom (1734), MacBride and Desperierres (1767), and Jervey (1769), recounted the various virtues of fresh vegetables, fruit juices, and vegetable brews and broths in the cure and prevention of scurvy as a disease of seamen.

Other pioneers in the use of fruit juice and extracts as anti-scorbutics, although not specifically for diseases of seamen, were Peter Forrest (1595) who made a syrup from scurvy grass, and Solomon Albery (1593), Felix Plater (1608), and Francis de la Böe (1674) the famous Leyden Professor, who all advocated the use of oranges.

Shore-side medical men were inclined to discount the effects of scurvy in ships and to attribute the poor state of health of the seamen largely to the professional incompetence of the sea surgeons and physicians, and in 1685 Sydenham went so far as to say "the two great subterfuges of ignorant physicians were malignity and the scurvy, which they blamed for disorders and symptoms often owing to their own ill management." Undoubtedly, the views of such eminent authorities went far to cause adverse decisions by the Admiralty when they were petitioned for a more wholesome diet, for the naval service was not popular with the medical profession at the time, and in 1692 the Barber-Surgeons' Company asked for a standing authority from the Lord High Admiral to impress surgeons and surgeons' mates.

Between 1708 and 1711 there took place the threeyear voyage round the world of the Duke and the Dutchess. The famous Dr. Dover sailed in the Duke, but despite his presence and the boast of her Captain, Woodes-Rogers (1712), that the means for preventing scurvy were well known, they buried the first man with scurvy on Jan. 1, 1709, having sailed the previous August.

The ravages that occurred when the antiscorbutics were neglected on long voyages were also well illustrated by the experience of Anson (1740-44) on his voyage round the world. By the time he reached Juan Fernandes, two of his ships, the Gloucester and the Centurion, had lost respectively three-quarters and three-fifths of their ships' companies, whilst the majority of the survivors recovered with the fresh provender they obtained ashore. This disaster provoked fresh enquiry into factors affecting the health of seamen, stimulated scientifically-minded men to explore the possibilities of ventilating warships, and probably caused Lind to intensify his study of preventive medicine which preceded the first publication of his Treatise in 1754.

Despite the ample evidence available in his elaborate review of literature and from his own personal experience, Dr. Lind attributed the disease to " First, an intense degree of cold ..." and then to other causes " such as indolence, close confinement, or a sedentary and inactive life," and he suggested exercise as a preventive measure ; but nevertheless he freely discussed the value of fresh vegetables, scurvy grass, cresses, and lemon juice, and finally recommended the acids " in oranges, and most ripening sub acid fruits as the most effectual preservatives against this distemper."

Perhaps Lind, a Naval physician, was to some extent influenced in summarizing the requirements for dealing with this condition by the politics and prejudices of the day. Certainly his conclusions are less forthright than the clearly expressed opinions of Bachstrom and Jervey, and later of Trotter and Blane, and in the early part of his book he seems inclined to discount the primary value of green vegetables.

He was very well aware of the value of Hales' ventilators for maintaining health, and he stressed the importance of ventilating regularly and the beneficial effects of the exercise thus induced. He also urged frequent bathing for ships' companies, but-correctly-did not associate these latter factors with the atiology of scurvy, unlike certain others at that time.

The attention of the Service and of scientific men was by now drawn to the essential facts, and wise commanders employed every resource to husband man-power on their long voyages. In 1776 Captain James Cook was awarded the Copley Gold Medal of the Royal Society when he described how he accomplished a voyage in the Resolution of three years eighteen days, through all climates from $52^{\circ}$ North to $71^{\circ}$ South, with the loss of one man only by disease, ". . . who died . . . without any mixture of scurvy." Each man received daily one, two, or three pints of sweet wort "doubtless one of the best antiscorbutic sea medicines," and twice a week a pound of " sour krout," whilst the surgeon found vegetable soup, lemons, and oranges "useful." "The crew were at three watches . . . and proper methods were employed to keep their persons, hammocks, bedding, clothes and etc., constantly clean and dry." Equal pains were taken to keep 
the ship clean and dry ; " and once or twice a week she was aired with fires," and " had also frequently a fire made in an iron pot at the bottom of the well, which greatly purified the air ... To this and cleanliness, as well in the ship as in the people, too great attention cannot be paid."

Cook believed primarily in cleanliness and ample fresh water : "I am convinced that with plenty of fresh water, and a close attention to cleanliness, a ship's company will seldom be much afflicted with scurvy, though they should not be provided with any of the antiscorbutics ....," but he used them assiduously all the same, and valued a mixed and fresh diet highly; "we came to few places where the art of man or nature did not afford some sort of refreshment or other, either of the animal or vegetable kind. It was my first care to procure what could be met with of either by every means in my power, ... . and to oblige my people to make use of them both by example and by authority."

He spoke highly of the constant help he received from his physician, William Anderson, both in caring for the wants of the men and also as a skilled naturalist (Keevil, 1933). They were constant companions on explorations ashore, and there is little doubt that Anderson's early death at the age of 30 years cut short a career of great scientific promise, either as a naval physician or as a biologist. His contribution to the achievement of the Resolution was certainly of major importance.

\section{The Ventilation of Sailing Ships}

Even in Elizabethan times Sir Walter Raleigh commented on the evils of poorly-ventilated spaces : "Cabins are but sluttish dens that breed sickness ..." (Shaw, 1929). From the time of the Tudors onwards the necessity for ventilating ships became increasingly apparent, as the open ships and single deckers gave place to three deckers and larger ships, in which men slept well away from the upper deck and lacked fresh air, especially when the gun ports were closed because of rough or cold weather.

Shaw gives a grim summary of conditions prevailing in ships during the eighteenth century : " Besides overcrowding and deficient ventilation ... the ships were damp, bilge water was often foul and its odour penetrated the whole ship. The men ... frequently were without changes of clothing; washing facilities were meagre, due to not only the very restricted water supply, but also the lack of soap ; and the numerous candles used for lighting purposes further contaminated the air . . . live stock were frequently accommodated on board ..." Rotting ballast further fouled the atmosphere. Vinegar was widely used to purify the air, and was wrongly thought to prevent the spread of infection.
Ships' companies were diluted with the unhealthy scourings of the seaboard towns who were " impressed" to serve in the Navy by the press gangs.

Although the physical nature of the convective effects of the fires between decks was incompletely - understood, their value was well appreciated in the seventeenth and eighteenth centuries not only for preserving the health of the men, but also for saving the timbers of the ships. The latter requirement possibly carried a higher priority than the former in arousing the keen interest shown in warship ventilation. Desaguliers (1727, 1735 ; quoted by Reid, 1844, Bernan, 1845, and MacDonald, 1881) was consulted by the Admiralty about 1740 as to whether "the centrifugal wheel and pipes" with which he had ventilated the House of Commons a few years earlier might be used to purify the air of ships; and at the same time Dr. Stephen Hales (1755) conceived a method of utilizing ventilators for the same purpose, which were worked by hand and had a bellows-like action. He 'described his invention to the Royal Society in May, 1741.

These devices, however, required men to work them constantly (these men were called the "ventilators" by Desaguliers, who called his machine a "blowing wheel"), and a more subtle solution was proposed by a brewer called Samuel Sutton (1744). He proposed to lead pipes from the hold or from other foul spaces below decks into the enclosed galley fire places beneath the coppers in which provisions were boiled; thus making use of the convective currents induced by the fire in place of the human operators. After trials ashore this economical system was installed in the Norwich in 1741, which then sailed on a tropical cruise for two years. On his return the Commanding Officer reported indifferently on the method, notwithstanding the sustained good health of his crew, which he attributed to the ship making enough water to " keep her sweet," presumably by flushing the bilges. However, Sutton's pipes were subsequently fitted in the Namur, Warwick, Sandwich, and Vigilant, and were received more favourably.

In the meantime Hales' ventilators were fitted into the ships of the slaving trade. It was remarked that the exercise of "ventilating" kept the slaves healthy, and the valuable cargo was excellently preserved by the improved air below decks, so' that the survival rate of slaves was said to be increased by as many as twelve times following the fitting of ventilators in five Nova Scotia slavers in 1749.

Apparently ventilators were fitted in warships as well, for in a further communication to the Royal Society in 1755 Hales quoted the experience of Captain Thomson of the Success frigate in 1749 : "Their rule for ventilating was half an hour every 
four hours but, when ... neglected for eight hours altogether then they would perceive, especially in hot weather, a very sensible difference by that short neglect of it ... There were two hundred men on board for almost a year yet he landed them all well in Georgia," and again ". . . the crew of this ship, which lay windbound for four months with the expedition Fleet which soon after invaded France, were very healthy all the time, when they were very sickly in all the ships of that expedition," a naturally controlled experiment.

Later Hales' ventilators were fitted at Haslar Hospital, and in other shore establishments, and in 1756 they were installed in the Royal George, "In which the Honourable, Admiral Boscawen, taking care to have them properly worked, they were found to have the desired good effect, so to refresh the whole air in the ship as to preserve in good health 850 people; which happy event occasioned their being ordered to be put into the whole Fleet." (Hales, 1758.)

It transpired, however, that although the inventions of Hales and Sutton were both proved in practice, they were frequently improperly used or not used at all, and before very long the old-fashioned windsails, always at the mercy of contrary winds, regained their place as the main standby for warship ventilation, and retained it for the next hundred years or so, coupled at times with the use of fires between decks to "dry the air."

The lively spirit of invention and rivalry in securing improved conditions for men in ships was occasioned firstly because the country was fighting naval wars for much of this century, and the Admirals, if not the Government, realized that men were the first machines of war, and that the country was going to run short of seamen if energetic measures were not taken to preserve their health, and, secondly, because the human cargoes to be carried from the Guinea Coast to the American plantations were of great commercial value. It paid to land slaves in good condition. But, although these incentives continued for some time, no notable progress was to be made in methods of ventilating ships until in place of men, steam and electrical power became available to work the fans.

\section{The Rise of Naval Preventive Medicine}

The greatly improved health of the Fleet towards the close of the century was discussed in the Despatches and Letters of Lord Nelson and in the writings of Gilbert Blane. In 1781 the latter reported from the West Indies that in one year, out of 12,109 seamen in twenty sail of the line, 715 died on board, 862 died in hospital (a death rate of 1 in 7), and 350 were invalided, whilst only twenty-four years later Nelson declared that during two years in the Mediterranean (1803-05), from amongst six to eight thousand men in ten to twelve ships of the line and three frigates under his Command, only one hundred and ten died (a death rate of 1 in 127), 141 were sent to hospital, and the average number sick was only eighteen to a ship.

The great attention paid by Lord Nelson to the health and morale of his men is repeatedly shown in his letters and despatches (Laughton, 1866; quoted by Turnbull, 1904). Thus in August, 1803, he wrote to Dr. Baird: "The last ships out, although they came to sea wretches, are generally speaking in the most healthy condition; they are in the best humour which is a great conducer to health." And again on Nov. 1, 1803, at Madelena : "... now upwards of five months at sea. But our health and good humour is perfection, and we only want the French Fleet out ..." ; and on March 11, 1804 to Dr. Moseley : "The great thing in all military service is health, and you will agree with me that it is easier for an officer to keep men healthy, than for a physician to cure them." In the same letter he showed his anxiety to keep the minds of the men active during periods of waiting : " ... yet I have, by changing the cruising ground not allowed the sameness of prospect to satiate the mind ..." Lastly he warns against false economy in a letter to Dr. Baird on March 18, 1804 : “ . . Bear in mind not to be penny wise pound foolish. A small sum well laid out will keep the Fleets healthy, but it requires large sums to make a sickly Fleet healthy. Health cannot be dearly bought at any price, if the Fleet is never sickly."

The improved health of the men in Nelson's blockading Fleet was attributed to the following causes by Leonard Gillespie, Physician to the Fleet at the time :

1. Good victualling. Good quality wine, fresh meat and vegetables.

2. Avoidance of wet decks. The ample use of stoves and ventilation.

3. The constant activity and motion in which the Fleet was preserved. They were always at sea, never idle, and there was no time for intemperance ashore.

4. Promotion of cheerfulness by music, dancing, and theatricals.

5. Great attention to the care of the sick.

6. The issue of Peruvian bark (cinchona) mixed with wine and spirits to men employed in "wooding and watering."

A consideration of these fundamental concepts, which the old Admirals put into effect, leads one to wonder how far the Navy has advanced since the general introduction of lime juice in 1795. Although a vast array of mechanical devices are now to hand, 
with power to drive them, and great advances have been made in the control of infectious disease, we would do well to consider if the importance of the human factor is rated as highly now as it was at times in the past, when the difficulties to surmount were vastly greater.

The great debt owed by the Navy to Lind, Trotter, and Blane as the founders of naval hygiene is well outlined in an anonymous review in the United States Naval Medical Bulletin (1920), which describes how they struggled against. "stupidity, ignorance, prejudice, and indifference in high places and low, in the Admiralty and the forecastle; they had the hard task of seeking to break down immemorial custom; dared to challenge tradition; ... and preached seemingly frivolous beneficent novelties to insular conservatism that held hardship essential for hardihood."

The part played by their varying personalities in the success they achieved is well shown: Blane, tactful, patient, and well-connected, and from the start the close friend of captains and admirals ; Lind, the pioneer, a genius for observation and deduction, a diligent student and- a careful writer, but disappointed by failure to achieve in his time the full credit he deserved; Trotter, a man of great energy as well as learning, had more sea service than either of the others and insisted on the need for sea surgeons and physicians to learn the problems of the Service by going to sea before they were given high places in the service of the Admiralty. He was a keen practical observer and appears to have had the good will both of sea surgeons and physicians and of medical scientists, such as Jenner, whom he greatly admired ; but he was in constant rebellion against what he considered to be the intransigent attitude of the Admiralty.

Lind speaks of "the preposterous custom of washing decks after sunset," and stresses the need for keeping ships dry. The idea that it was necessary to soak wood to season it before ships were built meant that the timbers of many ships were rotten before they were launched and menof-war rarely lasted for more than seven or eight years without complete overhaul. He considered the damp timbers to contribute greatly to sickness and pronounced Hales' ventilation system " the most beneficent invention for mariners which this age has produced."

Trotter (1797) probably provided the best review of the practical situation in ships and he wrote extensively of the evils of impressment, which he pronounced to be "the cause of more destruction to the health and lives of our seamen that all other causes put together." He strongly supported the arguments put forward by Lind and Blane for a general uniform to be issued to seamen, and expanded on the need for good ventilation, suggesting that " more attention be directed to the construction of pumps for dislodging a vitiated portion (of air), than has been bestowed on a machine that should fill up the vacuum by a purer column (of air)." He referred to the inconvenience of using scuttles and ports for ventilation purposes and the shortcomings of wind sails, and suggested the construction of "air flews" communicating with the upper deck and the compartments below. He gave, in fact, a nice account of the ends which warship ventilation should achieve.

Blane, in a foreword to his "Diseases of Seamen" (1799), says that when he joined Admiral Rodney's Fleet in 1780 the Admiral instructed him that every surgeon was to send him a monthly return, "stating the degree of prevalence of different diseases, the mortality, and whatever else related to the health of the prospective ships." This wise instruction enabled Blane to collect a wealth of information about the health of the Fleet then and in the succeeding years, and these nosological returns became the yardstick by which he measured the improyed health of the Navy during the wars -with France. He showed that the yearly proportion of those sent to hospital in all parts of the world to the number voted by Parliament for the Navy only changed from 1 in 3.3 to 1 in 4 between the years 1782 and 1795 , but had fallen to 1 in 10.75 by 1813 . This remarkable change was ascribed to the general measures discussed above and to the general issue of lime juice after 1795. There was little change in health during the next sixteen years, and in 1829 the above ratio rose to one in 8.9 , due to the increase of yellow fever in the Fleets.

He contrasted the experience of Lord St. Vincentwho in 1800 blockaded Brest with twenty-four ships of the line for four months without one of them being in port, and without sending more than sixteen men to hospital-with the experience of the Channel Fleet during the American War, which sent 6,064 men to hospital in a four-month period with fever and scurvy, and 2,500 on another occasion after a ten-weeks' cruise. In the first five years of the war with France the numbers of men admitted to the Hospitals at Plymouth and Haslar were 27,000 less than in the first five years of the American War, although there were more ships in the Fleet.

This was a further instance of the "good that cometh out of evil." Health at sea prospered under the conditions of war, when the wits of the commanders and surgeons alike were sharpened to husband all resources, although the conditions of service were hard indeed and long dreary periods were spent at sea. Blane states: "One of the 
most distinguished sea officers that ever lived declared to me, that it was his conviction that two ships now are equal to four of former times." At the same time there was still room for improvement. In the good year of 1813 he assessed the mortality in the Navy to be 1 in $42(24 / 1,000)$, or double the mortality for subjects of the same age in civil life on shore, greater even than the mortality amongst prisoners of war, and more than twenty times the average mortality in the modern Navy. He estimated that but for the advances made in preventive medicine the whole stock of seamen in England would have been exhausted before the conclusion of the Revolutionary War (1793-1815), and there seems little reason to doubt his logic:

Blane summarized the main measures by which this remarkable change was achieved as follows :

\footnotetext{
"The scurvy has been prevented, subdued, and totally routed out by the general use of lemon juice, supplied for the first time at the public expense in the year $1795 \ldots$ fevers have been extinguished (though not so rapidly as scurvy) by watchful attention to the following points; cleanliness, ventilation, dryness, sobriety, the separation of those in health from those affected with contagious fevers, and by a more general and deep impression on the minds of Commanding Officers, that one of their most sacred and indispensable duties consists in enforcing the means of preserving health, and that to them, more than the medical officers, belongs the duty of an unremitting vigilance with regard to all these regulations as points of discipline, now so well ascertained, by which the generation and the spreading of infection are counteracted."
}

He also considered the improved methods of recruitment and the reduction in the number of Press Gangs to be important contributory factors to improved health and morale, by eliminating many unsuitable and unhealthy men from the ships.

Blane did not lay over-great stress on ventilation, and he referred to the sheathing of ships with copper to preserve the timbers, which thus reduced one of the eighteenth-century needs for good ventilation. He claimed considerable credit for the general issue of lemon juice and soap to the Fleet, and stressed the part played by the better health of the British seamen, in comparison with that of the Frenchmen, in securing victories in sea fighting at close quarters ; and he postulated the important role of the Medical Officer in promoting fighting efficiency. He also observed : "Success in battle is one of the best general tonics for health."

Trotter (1797), and Gillespie (1798) did emphasize the importance of securing good ventilation and dryness by the frequent use of fires between decks and by rigging windsails, and also of personal cleanliness, wholesome clothing, thorough airing of hammocks and bedding, frequent baths in tubs or over the side; and the need for keeping men mentally occupied and in a happy frame of mind.

Gillespie directed attention to the need for reducing complements in tropical waters, and suggested an automatic reduction of one sixth of all ships' companies. Trotter insisted on the rigid isolation of the sick after cleansing to prevent the spread of disease, the routine inspection of men on joining the ship, and the importance of executive officers realizing their responsibility in the field of preventive medicine. He remarked : " ... nothing seems more extraordinary than the general neglect there is of working the fixed ventilators. They should never stand still for a moment"; and finally : "It has been wisely said that the fatherly care of a Commander is the Seaman's best physician."

The teachings of these naval doctors were hammered home later in the Instructions for the Physicians of His Majesty's Fleet (1825), where the use of hanging stoves for ventilating between decks and in the well was recommended, and it was laid down that "dryness, cleanliness and ventilation are the most effectual means to prevent diseases and contagion," and physicians were required to transmit to the Victualling Board at regular intervals :

1. Nosological returns of the state of the sick.

2. State of the weather and climate.

3. Height of the thermometer.

4. Any other circumstances influencing health.

There now began a period of peace which lasted many years. Such wars as there were mainly served as manœuvres for the Navy, which was busily occupied converting the wooden sailing ships into iron battleships driven by steam.

The standard publication of the Health of the Navy was commenced in 1840 , when Wilson covered the years $1830-1836$, at the direction of Sir William Burnett, and thus carried on the good work started by Blane at the injunction of Admiral Rodney. In his introduction details of victualling and of issues of spirits and lime juice are described which appear reasonable in the light of the times, and instructions for securing a healthy water supply and certain other standards are laid down. The usual space between the clews for hammocks was to be 14 to 18 inches, so that, "when they are extended by the beds, their bodies are in contact." Dry stoning the decks instead of wet washing was advised, and personal cleanliness was stressed. The influence of a happy and trained mind on health was also noted. Schoolmasters (instructors) were borne in ships after 1837, and ships' libraries were established in 1838 by Admiralty Orders.

The one field where little advance was made was 
that of ventilation. Windsails, although admittedly defective, were still the main standby, and Wilson states: "Though other methods have been proposed, they have either not answered, or have not yet been sufficiently tested to show their effectiveness" ; but he throws out a hope that an air pump designed by a Captain Warrington might soon be available by which pure air might be transmitted " through tubes led along the sides of ships." Thus it would seem that Hales, Sutton, and Desaguliers had been forgotten for the time being.

Since this time the Health of the Navy has been published annually and only discontinued in time of war. Thus we have no health records of the 1914-18 War after 1915, nor are records available for the latter part of the 1939-45 War, apart from those relating to invalidings and deaths, with the exception of certain limited information concerning health in the Eastern and Pacific Fleets in 1944 and 1945 (Ellis, 1947, 1948).

\section{The Ventilation of Steam Ships}

Interest in warship ventilation was aroused afresh in the middle of the nineteenth century by. the need for equipping three ships which were to go on an expedition to the Niger River to abolish slavery. (M'William, 1843). The farsighted Dr. Reid (1844) had advised on the methods of ventilating the ships by means of a power-driven " fanner," which was operated by kroomen when steam was not available, and was devised so that the entire air supply was drawn through a chlorinated filter, by which the intention was to purify it. The resistance of the filter obviously limited the input of air and led to differences of opinion between the medical officers of the different ships. One preferred to dispense with the filter and have a better air supply; the other considered better results were achieved with the filter in use. The expedition failed, but not apparently because of the heat, for the men remained fit in the tropics until they reached country which was heavily ridden with mosquitoes and fever.

Dr. Reid lays down interesting standards in his book on ventilation published after this expedition failed. He considered that for an uncrowded compartment, at an average temperature, air should be provided at a rate of ten cubic feet per person per minute, but he noted that considerable increases were required when numbers were high or if the air was heated; and stated that 100 cubic feet of air per man per minute might be less powerful in the tropics than one cubic foot of air in cold countries " in its power of absorbing moisture from the body."

He remarked on "the very different effects produced by the same atmosphere at the same temperature according to the rates at which it moves," and considered that "in England for men engaged in bodily work a temperature of $65^{\circ} \mathrm{F}$., with an atmosphere moving in a very gentle stream, so as not to be perceptible unless very marked attention be paid to it, is the most generally agreeable in rooms which are not overcrowded." This view, recorded over one hundred years ago, and the importance attached to the significance of air movement and of a varying moisture content of the air, accord closely with those held today (Bedford, 1946). Again one can only remark that, although mechanical devices have become increasingly ingenious and steam and electric power have been harnessed to a high degree of efficiency, the desirable qualities for the thermal environment in which men should live and work were known long ago and have altered little, but the provision made to satisfy these criteria frequently fails dismally.

Reid placed windsails in the correct perspective as valuable auxiliary aids to inadequate ventilation; he recommended the use of the convection currents created by the galley fire or by other fires as further ancillary aids; and he proposed the adoption of exhaust ventilation, to be obtained by power-driven fans, which would exhaust the air from the compartments through ventilation trunking distributed throughout the ships. He observed that this system could be converted to a plenum system by reversing the direction of the fans. Modern warship ventilation can be said to have evolved from this time onwards.

In the remainder of the nineteenth century, apart from minor mechanical developments, few new concepts were introduced which bear upon the matters under discussion. Various enthusiasts tried to solve the problems of ventilating ships by devices such as Arnott's Ventilating Pump or Edmond's "Steam Exhaust" system-which utilized the steam jet from the boilers-whilst others tried to use the draught of the funnel uptakes. In 1867 mechanical ventilating fans were installed in the Hercules, and in 1873 steam-driven fans were fitted in the Devastation, but MacDonald in his book on Naval Hygiene in 1881 still laid great emphasis on the value of windsails, natural plenum ventilation with uptake cowls and shafts; and numerous ports and scuttles; and artificial ventilation by centrifugal fans was still considered to be generally unpractical: Handworked Desaguliers' fans were, however, sometimes employed for magazine ventilation.

Methods of gas analysis were now used to assess the effectiveness of ventilation systems, and six volumes of carbon dioxide per ten thousand parts of air in compartments was considered to be the upper desirable limit for warships (normal $\mathrm{CO}_{2}$ 
content of air 4 per 10,000 ). It was calculated that a supply of three thousand cubic feet of air per person per hour would be necessary to comply with this standard, and thermal considerations were only of secondary importance.

The replacement of the wooden ships by steel battleships meant a sacrifice of the excellent insulating properties which the wood afforded against severe climatic conditions, to keep the ships cool in the tropics and warm in northern waters. The wooden upper deck was, however, retained, and where it is fitted it is still one of the most effective counter-measures against excessive solar radiation.

The use of portable handworked fans and air hoses for ventilating the double bottoms of iron ships throughout the time when men were working in them was stressed in the current Queen's Regulations and Admiralty Instructions, for the danger of entering unventilated confined spaces was generally known after a widely publicized but non-fatal accident in the pump well of the Minden in the year 1819, and the "lighted candle test" was advocated on the occasions when such spaces were opened.

Naval warfare remained a placid affair for the remainder of the century, and in the Queen's Regulations and Admiralty Instructions (1899), the injunctions of Cook and Nelson a century or more earlier were re-echoed :

" 1. The Captain will use his best endeavours to ensure cleanliness, dryness, and good ventilation throughout the ship, that all compartments are kept dry ... He is to take every possible means to ensure a thorough natural circulation of air through the ship at all times ...

4. If the weather should prevent the ports from being opened for a considerable time fires are to be lighted in the stoves, and windsails are to be freely used.

5. He is to see that the men are properly clothed?"

Electrically driven ventilation fans were installed at the beginning of the twentieth century in the Hogue Class Cruisers and the Canopus Class Battleships. The principle of " single compartment ventilation" was accepted, and in 1903 steam heating of the air supply was introduced to reduce icy draughts on the mess decks.

\section{The Admiralty Ventilation Committees of 1912 and 1937}

In 1912 Their Lordships convened an Admiralty Ventilation Committee, of which Professor J. S. Haldane, F.R.S., was a member. This committee presented its Report in 1914, after conducting a thorough investigation of ship conditions and numerous practical experiments. They recommended inter alia :
1. An air temperature of 55 to $60^{\circ} \mathrm{F}$. for compartments in cold weather, and a somewhat higher temperature for hot weather.

2. That ventilation should be such that in the hot engine rooms and auxiliary machinery spaces a rise of temperature exceeding $30^{\circ} \mathrm{F}$. above that of the outside air should be prevented at places where men may have to stay for some time, and that "when the wet-bulb temperature exceeds $85^{\circ} \mathrm{F}$., it max be necessary, to carry out relief at short intervals."

3. That the plenum system should be adopted before the exhaust system in living spaces.

4. That the proportion of carbon dioxide in the atmosphere should be kept below 7 volumes per 10,000 volumes of air by adequate ventilation, which should be of the order of 3,000 cubic feet per man per hour (50 cubic feet per man per minute).

5. That a space of 200 cubic feet per man should be provided in messing spaces, and that the spacing between the hammocks should not be less than 20 inches.

6. That the air supplied through the ventilation trunking should be warmed by "indirect" heating for use in cold climates.

Special recommendations were made to cover the control of " wild heat " by fitting adequate insulation to prevent the emission of heat radiation from hot bulkheads heated by the sun or by machinery, from hot steam pipes, from the machinery itself, and from hot exhaust ventilation trunks and funnel uptakes. These were factors with which Nelson did not have to contend, and with the added factors of increasing compartmentation and watertight subdivision of ships marine ventilation was becoming a most complicated problem.

The recommendations of the Committee were put into practice in the 1914-19 I8 .War, which was fought mainly in temperate and northern waters where the warmth of ships' companies was an important consideration, and the dirty evolution of " coaling ship "-added to the hygienist's worries.

Following the declaration of peace there were few changes for several years. Dudley (1928) called attention to the high temperatures recorded in the tropics even in peacetime in H.M.S. Dunedin, and, together with Shaw (1928), reiterated Dr. Reid's emphatic statement of eighty years previously at the start of the "steam -age," that adequate air movement was essential to the comfort and wellbeing of men below decks in the tropics. He made a strong plea for adequate supplies of fans for circulating the air within compartments as well as for supplying air to them.

Shaw in his book on naval hygiene (1929) showed the importance of medical statistics in evaluating the results of preventive medicine, and divided his subject into "individual hygiene," which by then had reached a high standard, and " environmental 
hygiene," which was limited by the rigid considerations of warships where space was at a premium and also by the practical limitations to defining optimum thermal conditions below decks for ships which must operate all over the world. Ventilation was still designed to limit undesirable accumulations of carbon dioxide rather than with the aim of controlling the thermal environment, but he drew attention to the methods for assessing the thermal conditions which were most suitable for employment in ships, and described the sling hygrometer, the unsilvered dry and wet kata thermometers (cooling range 100 to $95^{\circ}$ F.), and the vane anemometer. He recommended $62^{\circ} \mathrm{F}$. as the optimum temperature for living spaces.

In 1937 the Admiralty convened another Ventilation Committee, which was directed primarily to consider the problems of magazine ventilation and the potential hazard of carbon monoxide poisoning following underwater explosions. Sir Leonard Hill, F.R.S., served as a member on this Committee.

As far as the living and working conditions of the men were concerned they accepted standards which fell below those of the Committee of 1912 in certain respects. These-decisions were necessitated by the considerable increases in ships' complements and equipment which were necessary to keep pace with the rapid advances in methods of making war, and were aided by the establishment of new criteria for defining efficient compartment ventilation. These required that the chemical standard hitherto employed, which aimed at controlling the level of carbon dioxide in the air, should be replaced by a thermal standard, which aimed at the control of compartment warmth rather than the chemical purity of the air.

It appeared likely that the adoption of the new standard would lead to certain difficulties. The range of environmental conditions encountered in any ship varies widely, and it was appreciated that the fresh air requirements of the various compartments would vary greatly, not only from compartment to compartment but also in the different parts of the world. It was planned to meet the former difficulty by varying the size and power of the fans supplying air to and exhausting air from compartments, and to cope with the latter by installing " two- or three-speed" fans as a general rule. The correct operation of the ventilation system to meet the needs of the men now needed considerable skill and thought from the ships' officers, and the maintenance of numerous fans and great lengths of ventilation trunking threw heavy additional burdens on ships' electrical and engineering staffs.

The quantity of air to be supplied to the messdecks was reduced from 3,000 cubic feet per man per hour ( 50 cubic feet per minute) to 2,000 cubic feet (33 cubic feet per minute) if possible, and to a minimum of 1,500 cubic feet ( 25 cubic feet per minute). The number of air changes per hour per compartment was allowed to vary from 60 in engine rooms to 6 on the messdecks, or 3 in lobbies which were not continuously occupied. Thus, although ships were becoming more crowded and warmer, a reduction in ventilation of the lixing spaces was at times accepted.

This Committee found that the existing practice in ships only allowed on an average 120 cubic feet of space to accommodate a man on a messdeck, with an average space of 18 to 20 inches between the clews (suspension points) of hammocks. As it was desirable to keep at least three feet between the heads of men, in order to prevent airborne spread of infectious diseases, they recommended that ratings should sling alternately head to foot. It was appreciated that this did not conform with the most desirable standards of barrack hygiene.

They recommended an air temperature of 60 to $65^{\circ} \mathrm{F}$., for cold climates, the general adoption of high velocity ventilation terminals, and the continuation of heated air supplies for northern waters, but considered that air-conditioning of compartments was not essential in a warship. The problems of tropical warfare were not considered in any detail.

The last observation of historical importance was made by Forbes-Guild (1940), just before the outbreak of the 1939-45 war, in a sloop in the Persian Gulf. He showed the value and limitations of a portable air-conditioning plant, obtained locally and not designed for shipboard use, not only in improving the living and working conditions, but also in treating and averting cases of heat stroke and heat exhaustion which are not uncommonly encountered in that excessively hot part of the world.

\section{The Results of Naval Preventive Medicine}

Shaw (1929) was able to show remarkable improvements in the Navy since the Annual Health Report was instituted in 1856 . These were largely due to the influence of preventive medicine. Thus the average death rate per thousand men of the total force fell from 14.34 in the years $1856-60$ to 4.87 for $1881-90$, then to 2.47 during 1911-15, and finally to 1.4 for the year 1926 . The average daily number sick per thousand men fell from 53.6 for the period $1856-60$, to 31.8 for $1900-09$, and to 20.45 in 1926. The final invaliding rate fell from 18.12 per thousand for $1900-09$ to 12.9 in 1914 , rose to 24 in 1915, owing to the call-up of the unfit, and remained at the relatively high level of 18.12 in 1926 , 
this possibly being due to the greater discrimination shown by that time in eliminating unhealthy men from the Service.

As instances of the way in which preventive medicine improved naval health, Shaw mentioned the reduced incidence of enteric diseases from 2.07 per thousand (1900-09) to $0 \cdot 11$ in 1926 , the rarity of undulant fever-the one-time menace to the Mediterranean Fleet-and the virtual elimination of scurvy, small-pox, typhus, and yellow fever from the naval community, although he indicated tuberculosis, pneumonia, diphtheria, and venereal disease as illnesses requiring, at that time, further measures to secure their prevention.

In connexion with the above figures it is of interest to consider the annual rates for invalidings and deaths between the years 1934 and 1943, which show that before and during the early years of the war the death rate was $1 \cdot 1$ per thousand, an improvement on the figures considered hitherto and less than one twentieth of the rate in 1813.

\section{Conclusion}

When Great Britain declared war in 1939 the Royal Navy had not for over 130 years conducted major fleet operations which involved ships remaining continuously at sea in the "battle state" in tropical waters.

During this time the environment of the sailor had changed greatly. Wooden sailing ships, largely at the mercy of the wind, had been replaced by steel coal-burning or motor-driven vessels. The main causes of man-power wastage in the pastdietary defects, which produced scurvy and other deficiency diseases, and poor ventilation and a low standard of preventive medicine, which allowed the rapid spread of infectious disease on the messdecks - had been corrected to a very large degree; but the thermal environment below decks, despite the advances in ventilation, was probably more severe than in Nelson's wooden ships, for Blane (1830), in his careful summary of the factors contributing to naval ill health, does not even refer to the adverse effects of excessive warmth.

Furthermore, ships' companies nowadays live " in " ships, not " on" them as was more customary in sailing ships, except perhaps in the tropics where the warmth below decks may drive many up on deck if air-conditioning of living and working spaces is not available.

A first-class knowledge of seamanship is an essential attribute of only a limited proportion of the men who now decide to make the sea their career, and the importance previously focused on the seamen now applies equally to men working in machinery spaces and in wireless or radar offices, to those manning gunnery control positions or fighter direction offices, or to those maintaining aircraft in the hangars of carriers. Other men are required for highly responsible and technical duties in submarines. The demands for skill, judgment, good powers of concentration, initiative, and ability to make rapid decisions, frequently exceed the former primary requirement for hardiness or toughness in a member of a warship's complement.

The conflicting needs for equipping ships with increasing numbers of weapons and technical devices and augmenting their crews with additional men to operate and maintain them, and for providing the crews with optimal environmental conditions to enable them to use the equipment efficiently, impose difficult decisions. on the naval staff who lay down the requirements which the naval constructors try to meet in designing new ships.

Ideally, these staff requirements should specify the optimum thermal conditions which should be achieved under different external conditions, should lay down the space required for each man on the messdeck, and should state the amounts of fresh air which should be supplied to occupied compartments under different conditions to ensure the maintenance of satisfactory air hygiene with normal occupation; but the indefinite nature of scientific knowledge relating to such factors as these, especially with reference to extreme climatic conditions, has led in the past to guarded or incorrect statements from medical men when they have been taxed by the staff to make positive recommendations.

We need to know more about many of these environmental factors, and within recent years much research outside the scope of the present review has been put in hand to fill some of the more pressing gaps in our knowledge, for the war with Japan showed strikingly how little our ideas had changed since Dr. Reid advised the Admiralty a hundred years ago on the fundamental principles to follow in designing ventilation systems for warships in the tropics.

A century's progress in the art of ventilation engineering, and the large-scale development of methods for cooling and dehumidifying air supplies in the twentieth century, have placed at our disposal the means for providing the occupants of warships in the tropics with thermal conditions compatible with the full maintenance of health and efficiency, provided the physiologists will define clearly the conditions which the designers must meet. In the same way optimal conditions may also be achieved below decks under arctic conditions by the application of modern methods of radiant heating or 
heated air supplies, but again the physiologists must state clearly the desirable conditions under which men should live in these extreme climates.

.It is not intended to refer in detail here to the conditions which were encountered in warships in the 1939-45 War, to which recent references have been made elsewhere (Critchley, 1945 ; Ellis, 1947, 1948); nor will space allow the examination of more than a small part of the evidence available in the chronicles of naval medicine, and of the voyages of the past.

It will be seen, however, that in the past disease in the Fleet always rose to a peak when large numbers of landsmen were impressed in times of crisis, and declined when the landsmen had learned to become seamen under the conditions of war. This period of learning frequently coincided with a heavy manpower wastage from preventable disease and malnutrition, and an increasing realization on the part of commanders that if they were to maintain a healthy and efficient fighting force they must ensure reasonable standards of air hygiene and must feed and clothe the men adequately. These points are well illustrated by the events of the Elizabethan and Napoleonic Wars, and towards the end of the latter it was confidently stated that, despite the fact that the French had designed more efficient fighting ships, the British sailors enjoyed a better state of health and their morale was higher. This was a vital factor in securing victory, and was undoubtedly largely attributable to the prolonged endeavours of the great admirals and the sea surgeons and physicians.

When wars ended, however, demobilization of the Fleet rapidly followed, naval funds disappeared, and the lively spirit of invention which had been nourished by the urgent needs of war evaporated. Lip-service frequently continued to be given to the need for preserving the welfare of the men; but, although committees and commissions met to consider their wants from time to time, the recommendations made in time of peace were frequently unreal and out of keeping with the conditions of war, and suggested an unwillingness to face up to what might happen in the next war. All wars in the past seem to have been " wars to end war."

It was an unfortunate fact that the two Admiralty Ventilation Committees which met during the present century assembled after many years of peace when the lessons of the earlier wars were not fresh in the minds even of the naval executive officers concerned, and little account was taken of the severe conditions which might have to be faced in naval warfare under climatic extremes. It was even more unfortunate that these Committees closely preceded the outbreak of fresh wars, and there was inadequate time to implement many of the good recommendations that were made, whilst the new conditions of the new war caused a revision of others before they were put into practice.

In the past, scientists were usually called in to assist naval ventilation committees by advising on the conditions conducive to the maintenance of health and efficiency and on the ways of achieving them, and the naval interest in these problems undoubtedly. served as a stimulus for certain individual researches which were undertaken on the problems of environmental hygiene. It appears, however, that the suggestions of the scientists were frequently only partly accepted, and their recommendations were not fully implemented, or else they were followed up with lack of energy and imagination, or with unwillingness to appreciate the practical problem, so that they were ineffective in practice. The whole neglect however, did not lie in material deficiency, waning interest, or inadequate or incorrect facts, but also in the official failure to promote planned research into the wide fundamental environmental problems involved.

This is an appropriate time, when the pattern of naval warfare in the future may be in the melting pot, to see that these mistakes are not repeated. Emphasis on the need for research is high at the present time, and the environmental problems which impaired health and efficiency in the 1939-45 War have been referred, since 1942, to the Royal Naval Personnel Research Committee of the Medical Research Council. This Committee considers on behalf of the Admiralty the physiological and psychological research necessary to add to fundamental knowledge and the ways of carrying it out. The problems of the thermal environment in ships are numerous and difficult, but they are being tackled by several teams. of workers from the physiological and psychologicat aspects, and also by ventilation engineers, who try to meet the recommendations of the physiologists by improved equipment design. The basic work is well in hand, but the research workers still depend for a realistic appreciation of things as they are in the Fleet on the reports of observers with the Fleet, and on such routine returns as those made in accordance with recent Fleet Orders which relate to the health of ships' companies and to the assessment of undesirably warm thermal conditions.

There is thus considerable activity at the present time, and the degree of success achieved in providing ships' companies with an optimal environment in which to live and work under cruising and action conditions in the future will be largely assisted by its continuation, for many of the complexities have not yet been tackled whilst othe 
are not even clearly defined. The nutritional aspect of life in the arctic or tropics almost certainly merits further attention, to give one example, and the evidence on which we base the human requirements for cubic space or floor space on the messdecks and the criteria for the design of sleeping arrangements may well be reviewed in the light of modern developments.

This is, however, only part of the picture. Those sections of the Admiralty which state the requirements to be met when new ships are designed and built are closely associated with the research workers, and so are the designers. Thus the chances are relatively good that if new principles be discovered relating to man and his environment they will be given careful consideration when the difficult compromises between the many staff requirements for a fighting ship are framed in the future.

Trotter's dictum that "the fatherly care of a Commander is the Seaman's best Physician" is as true today as it was a hundred and fifty years ago. The skilful handling of ships, the careful maintenance of machinery, wise routines for operating it, and a well-judged balance between damage control precautions and the maintenance of reasonable habitability, will always be important when only a limited margin can be allowed to cover misuse or neglect of the equipment that is provided. The captain of a ship is always the principal hygiene officer, and the medical officer is only one of his advisers, with a relatively minor though important role to perform. On the other hand the medical officer's contribution to the fighting efficiency of his ship may be considerable and may extend far beyond his purely professional terms of reference for preserving health, curing disease, and treating injuries.

It would seem that an extension of the present lively interest in the environmental problems of the men in relation to their efficiency and health under all conditions of service will offer an excellent chance for enabling the "human machines"-as well as the weapons and mechanical devices they operate-to work with optimum efficiency under the conditions of modern war, and will thus enable us to keep faith with the early sea surgeons and physicians and the admirals who laid the foundations not only of naval hygiene but also of naval personnel research.

I am indebted to the Librarians of the Admiralty Library and of the Library at the Royal Naval Hospital, Haslar, for access to most of the historical works to which references are made, and to Miss w. W. Keevil, D.S.O., and Dr.

\section{REFERENCES}

Admiralty Ventilation Committee Report (1914). H.M. Stationery

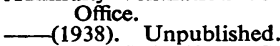

Allison, R. S. (1943). "Sea Diseases." London.

Anonymous. (1920). Nav. med. Bull., Wash., 14, 563.

Bedford, T. (1946). Med. Res. Council." War Memorandum, No. 17 London.

Bernan, W. (1845). "History and Art of Warming and Ventilating." London.

Blane, G. (1799). "Observations on the Diseases of Seamen."

London.
(1815). "Comparative Health of the British Navy." London.

(1822). " "Select Dissertation on Medical Science." London.

(1822). " "Select Dissertation on Medical Science." L

Callender, "G. (1945). "The Naval Side of British History." London.

Clark-Kennedy, A. E. (1929). "Stephen Hales, D.D., F.R.S."

Cockburn, W. (1696, 1736). "Sea Diseases." London.

Cook, James (1779). Philos. Trans., 66, 402.

Critchley, M. (1945). Brit. med. J., 2, 145, 173, 208.

Desaguliers, J. T. (1727). Philos. Trans., 35, 353.

(1735). Ibid., 39.

Dudley, S. F. (1928). J. R. Nav. med. Serv., 14, 77.

Ellis, F. P. (1947). Brit. med. Bull. (In the press.)

Ellis, (1948). Brit. med. J., 1, 587.

Ellis, H. (1751). Philos. Trans., 47, 211.

Fletcher, C. (1786). "A Maritime State Considered as to the Health of Seamen." "Dublin.

Forbes-Guild, W. J. (1940). J. R. Nav. med. Serv., 26, 262.
Gillespie, L. (1798). "Advice to Commanders and Officers of His Majesty's Fleet Serving in the West Indies." London. Majesty's Fleet Serving in the West Indies." London. Station." "Observation

Hales, S. (1755). Philos. Trans., 49, 332.

(1758). "Treatise on Ventilators." London.

Hill, L., Fiack, M., McIntosh, J., Rowlands, R. A., Walker, H. B. (1913)." "The Influence of the Atmosphere on our Health and Comfort in Confined and Crowded Places. Smithsonian Miscellaneous Collections." Vol. 60, no. 23.

Keevil, J. J. (1933). "Annals of Medical History," Vol. 5, n.s. p. 511. Laughton, (1866). “Nelson's Letters and Despatches. Admirals Despatches. Mediterranean (1803)." 31, 272.

\begin{tabular}{l} 
Despatches. Mediterranean (1803)." $31,272$. \\
Lind, J. (1754). " A Treatise on Scurvy.", London. \\
\hline
\end{tabular}

MacDonald, J. D (1881). "Outlines of Naval Hygiene." London.

MacDonald, J. D. (1881). “" Mutlines of Naval History of the Niger Expedition (1841-42),"

Moore, A. (1911). St. Bart's Hosp. Rpts., 47, 67.

Queen's Regulations and Admiralty Instructions (1899). Article 529.

Reid, D. B. (1844). Illustrations of Ventilation. London.

Shaw, T. B. (1928). J. R. Nav. med. Serv., 14, 1.

-1929). "Manual of Naval Hygiene." London.

Sims, A. J. (1945). Inst. Naval Architects. April 17, 1945. Sutton, S. (1744). "A New Method of Extracting Foul Air out of

Trotter, T. (1797). "Medicina Nautica." London.

Turnbull, A. (1904). "History of the Naval Medical Service." In the Library, R.N. Hospital, Haslar.

Turnbull, W:(1806). "The Naval Surgeon." London.

Underwood, E. A. (1947). Ann. R. Coll. Surgeons, 1, 115.

Wilson, J. (1841). "Health of the Navy, 1830-1836." 